\title{
The Role of Social Media Use in Social CoOrdination among Relief LOCAL ORgANIZATIONS DURING RESPONSE to Humanitarian Crisis in Yemen
}

\author{
Ahmed Salmen \\ University Malaysia Kelantan \\ salmeen15@gmail.com \\ Mokhtaruddin Ahmad \\ Multimedia University \\ mokhtarrudin@mmu.edu.my
}

\begin{abstract}
The extreme levels of uncertainty and complexity surrounding disaster relief operations call for the rapid diffusion of information. Thus, to collect and share information, humanitarian organizations have become largely dependent on Internet-based social media platforms. This paper presented a field study examining the effective way information can be diffused for the coordination of relief local organizations during their response to the humanitarian crisis in Yemen. The study made use of a statistical method of quantitative to obtain the results through social media use in access decision-making information of response and promotion of social coordination among the local relief organizations and study of humanitarian needs and the equitable distribution of relief. This finding is indicating information posted on social media during a disaster was exhibited expediently compared to other means of dissemination that provides needed information at later disaster phases, however, the participation in the diffusion of information decreases with more communications.
\end{abstract}

Keywords: social media, access to information, knowledge sharing, interactive participation, social coordination and humanitarian crisis.

\section{INTRODUCTION}

Over the past few years, communication technology has been acknowledged for its integral role in managing humanitarian crisis (Stephenson \& Anderson, 1997). Although the communication technology use plays a major role in the four specific humanitarian crisis management phases (i.e., mitigation, preparedness, response and recovery), majority of the use has been confined, in tradition, to response and recovery (Yemen, 2015). The current information and communication technologies (ICT) and information technologies (IT) that 
have been launched in the past 20 years have led to avenues of various communication systems integration.

More importantly, the interoperability of various communication systems has increasingly been enhanced in light of functioning as evidenced by the Internet, mobile phone, e-mail, radio, fax and TV (Tucker, 2011). As a consequence, ICT application in mitigating and steering clear of disasters has been proven to be effective. Also, the applications' social and technical aspects in the face of humanitarian crisis management have been successful (Stieglitz \& Ehnis, 2018). Currently, social media has played a central role in the proliferation of accurate information during humanitarian crises, and consequently, victims of the crises and assisting entities can share information and relay assistance requests (Kapoor et al., 2018).

Thus, the use of social media in coordinate among organizations can help cancel duplication in action efforts, poor planning and implementation of efforts, and minimize lack of awareness among humanitarian organizations on the developing crisis. As, they help to ensure that member organizations have access to the best information and communication technologies and practices when assisting during or after humanitarian crises (Tchouakeu et al., 2011). When using social media, common coordination problems in emergency response can be resolved, such as finding missing persons and facilitating communication between volunteers (Yates \& Paquette, 2011). Therefore, this study focuses on the study of the use of social media in the development of coordination between local relief organizations during the humanitarian crisis in Yemen.

From the above, it is clear that social networking sites such as, Facebook and Twitter paves the possibility for internet usage in exploring and maintaining the monitoring of societal changes and citizens' preferences, and as such, social media can be deemed as a significant data source that is useful for public opinion monitoring in the crisis cases (Ceron et al., 2014). Even though social network programs provide new tools for exchanging tacit knowledge and information, via interactive and collaborative technologies, the lack of understanding of the way social media contributes to the facilitation of the relief response during natural crises still exists (Panahi, Watson \& Partridge, 2012). On the whole, this adds to the development of online community participatory role, which promotes productive and social efforts of volunteers online (Postigo, 2009).

In that view, the main way that social media to participation enriches during the humanitarian crisis is facilitating contact and information exchange among people or organizations during humanitarian crises who have met each other offline, this same confirmed from uses and gratification and social exchange theories (Zakour, 2008). Therefore, enriching the incipient relationship. When organizations disclosing information about oneself, inquiring about others and replying to others' comments, organizations can transform mere distant acquaintanceships into possibly even stronger ties, thereby increasing social coordination levels among organizations (Liu, Ainsworth, \& Baumeister, 2016).

In a related study, Dantas and Seville (2006) stated that the information coordination, gathering, synthesis, interpretation and communication throughout varying organizations have become a top challenge in crises response. Notably, the collecting and proliferation of authentic and accurate information during a crisis often results in its delayed resolutions. This is exemplified by the Katrina disaster in the U.S., where the decisions makers were delayed in making decisions in the face of unclear and ambiguous information, which delayed the resolution of the crisis (Leidner, Pan \& Pan, 2009). Hence, decision-makers have to gather 
information to assess the scope and nature of the crisis before they can respond to it, and this necessitates the mitigation of information and communication via social media channels in order to respond on time (Reuter \& Kaufhold, 2018). In the absence or lack of information, the challenges of crisis response can multiply since the need to act clashes with the need to gather authentic needed information (Noonan et al., 2016).

\section{THEORETICAL AND CONCEPTUAL FRAMEWORK}

This study based on the theory of Uses and Gratifications (U\&G) theory and in this regard, The U\&G theory is one of the most widely used theoretical communication theories linking needs and gratifications with media choices (Liu, Fraustino, \& Jin, 2015; Ruggiero, 2000). While other scholars were focusing on media effects theory in the 1970s, Elihu Katz was interested in the audience's active role in choosing media. According to Katz, Blumler, and Gurevitch (1973), it is evident that people are aware of their media choices and why they actively chose certain media over others.

In the context of humanitarian crises, gathering needed information is among the satisfactions acquired from social media. Thus, this study considers U\&G theory proposed by Blumler and Katz (1974) to underpin the study's theoretical framework. The theory proposes that non-profit organizations use social media to satisfy their need to gather information on the crises and this is opposite to the assumption that the audience comprises of endogenous masses that passively receive the messages circulated in the media (Kaye \& Johnson, 2002). The U\&G theory addresses the media use among people to meet their needs (Katz, Blumler \& Gurevtich, 1973) and in this study, the researcher considers this theory invaluable to determining why users turn to social media use as a crisis response. Therefore, this study seeks to apply uses and gratifications theory to help explain why organizations use social media during humanitarian crises (Williams \& McCarty, 2012). In the case of Yemen, In line with Maxwell's (2012) study, U\&G is deemed appropriate to be used to examine disasters in the country. More importantly, the two-way nature of social media calls for the selection of the right medium by the audience and their usage of it.

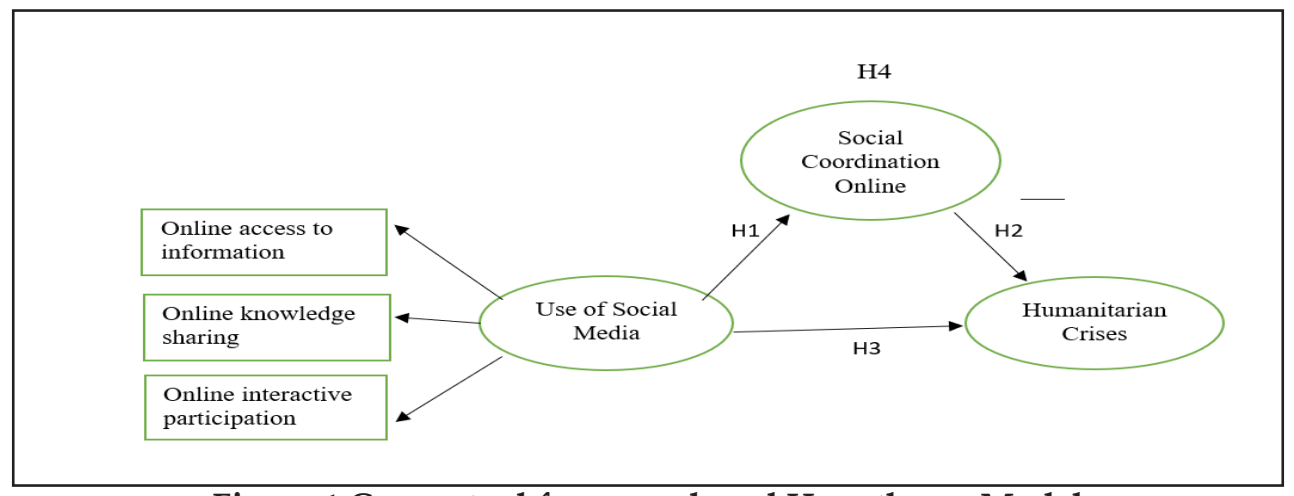

Figure 1 Conceptual framework and Hypotheses Model

In this study, the conceptual framework comprises of three variables, which are independent, dependent and mediating variable, with the primary aim of the study being the examination of the mediating role of social coordination on the social media use (independent variable)response to humanitarian crisis (dependent variable) relationship. More specifically, prior 
studies (de Zuniga, Jung \& Valenzuela, 2012; Westerman, Spence, \& Van Der Heide, 2012; Ellison \& Lampe, 2011; Castillo, Mendoza, \& Poblete, 2011) referred to a mediating variable as an independent variable contributing to the conceptualization of the relationship between a second independent variable and a dependent one. Figure 1 shows the conceptual framework and hypotheses model.

Thus, the following hypotheses are proposed by this study to be tested:

H1: Social media use has a significant and positive influence on social coordination online.

$\mathrm{H} 2$ : Social coordination online has a significant and positive influence on response to humanitarian crises.

H3: Social media use has a significant and positive influence on response to humanitarian crises.

H4: Social coordination online mediates the relationship between social media use and response to humanitarian crises.

\section{LITERATURE REVIEW}

In this section, the researchers will cover three main concepts for this study namely, use of social media, online social coordination, and response to humanitarian crises.

\section{Use of Social Media}

Social media refer to interactive digital/mobile tools that enable users to access, create or influence content (Wright \& Hinson, 2009 cited by Liu, Fraustino, \& Jin, 2015). This definition is centered on interactive participation, information access and knowledge exchange, which are the significant properties of social media. Consistent with the dynamic advancements of technology, social media has become increasingly widespread and popular in their use for sharing and accessing information, and this is particularly true during natural disasters throughout the globe (Chou \& CAI, 2005). Thus, social media is generally used for sharing and obtaining information during the occurrence of crises all over the world (Liu, Fraustino, \& Jin, 2015).

The past has witnessed social media's publication of disaster accounts after the fact but in the current times, social media is used as a valuable information source to acquire situational awareness during a disaster and following it. In recent times, the potential of social media as information source has been recognized and acknowledged among disaster relief agencies. For instance, the first natural disaster where social media was openly utilized to spread information about disaster awareness and preparation was Hurricane Irene (Kumar, et al., 2011). In 2015, social media was the fundamental tool used to respond to decision making during the Chapala floods in Yemen (United Nations, 2015) (see Figure 2).

Current studies showed that social media use is gradually becoming significant as the main information source during the occurrence of a crisis. This is exemplified by Sutton et al.'s (2008) study, where the authors investigated the 2007 wildfire disaster in Southern California, U.S. According to their findings, peer-to-peer communication using social media (social networking sites, text and instant messaging applications, blogs, wikis and other web forums) were extensively used to support the spread of critical and accurate information in the affected public sphere. 


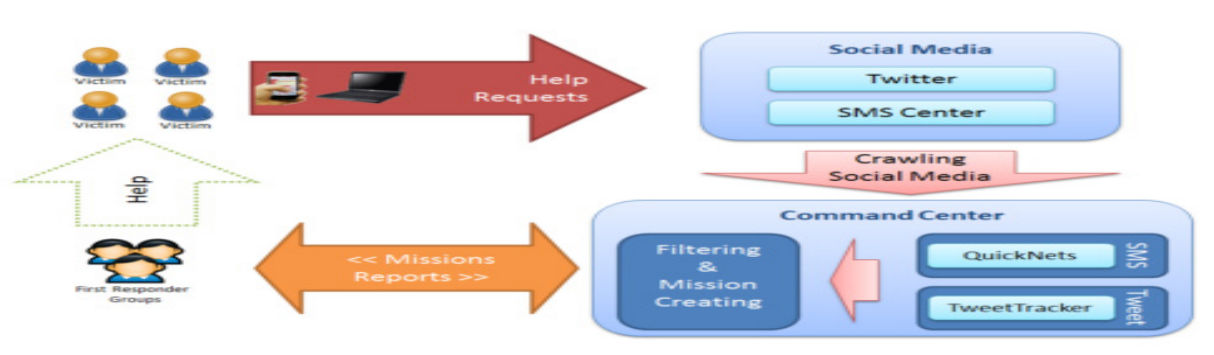

Figure 2: Communication by social media in response to humanitarian crises (Abbasi et al. 2012)

Along the same line of study, Alexander (2014) related that social media can be used in seven different ways to respond to humanitarian crises and they are; to listen to public debate, to monitor situations, to extend emergency response and management, to enable crowdsourcing and collaborative development, to create social cohesion, for charitable donations and for enhancing research. Hence, in the times of crises (e.g., flood), group cohesion is expected to be strengthened, with the realization of the community members of the significance of cooperating to meet the desired goals, which is community reconstruction following a disaster. Chang (2010) explained that disasters frequently destroy the cohesion among community members, with the interests of individuals superseding those of the community.

\section{Online Social Coordination}

In disaster events, online social coordination assistance is of utmost importance in the provision of effective humanitarian assistance operations but studies to this effect have only been few and far between. This is particularly true in terms of evaluating the interorganizational coordination during disaster relief activities (Moore, Eng, \& Daniel, 2003). The heart of the issue in disaster relief organizations is coordination as it focuses on the design protocols and mechanisms of activities management among government and nonprofit organizations (Goolsby, 2010). Based on the reviewed literature, social media can be used to generate a crisis map of the community and generate interagency maps, enabling organizations to bring about information sharing and collaboration for the achievement of the united mission. Social media allow the sharing of information among organizations operating on a single platform or using similar data representation formats (Scalese, 2012).

It is valuable to integrate community-based groups in issues related to disaster relief and decision-making, acknowledging that various factors (social capital, resources and expertise) are needed in creating a balance between actual considerations, and in tackling challenges relating to the public disaster relief operations, reaching decision making and establishing credential boundaries (Wachtendorf \& Kendra, 2004). Stated clearly, human and physical capitals along with coordination related norms and networks facilitating group activities are all often overlooked during crisis response and thus, it is crucial to consider social capital as the actors within networks and social structure that bring about mobilization (Dynes, 2002).

Majority of organizations are inclined to get involved in disaster response but it is quite challenging to coordinate among them during a crisis. Thus, it is feasible to determine the organizations and individuals working with them beforehand via social capital as they hold resources and skills required. Building social capital, keeping organizations abreast of 
the emergent needs (Kendra \& Wachtendorf, 2006) can help in determination, exploitation of interconnectedness of society and effect of people and economies on local, regional and national levels. The acknowledgement of this interconnectedness, the response and recovery levels of disaster management can pave the way for the use of inherent adaptable public and private capabilities to reinforce the resilience of the community. In so doing, local communities can affect others (individually and as a whole) (Stewart, Kolluru \& Smith, 2009).

Along with the evidenced positive effect of social media on disaster relief efforts, social media can also provide the capability of coordination for information, resources and plan sharing among the disparate relief organizations and for gathering information from disaster areas and drawing up data to reach informed decisions (Gao, Barbier, \& Goolsby, 2011). Consequently, crisis management greatly hinges on the platforms of social media to boost the community's participation during crisis. However, challenges abound among formal and informal organizations as to the work system cooperation (Purohit et al., 2014).

Information is central to improving inter-organization coordination during crisis response process and the coordinated ICTs deployment and coordinated information management processes are significant tools for information provision. Nevertheless, multilateral relief organizations coordination may still face problems in coordination (Saab, Maitland, \& Tapia, 2008). In fact, historical relations among organizations, common aim, common language, relevant organizations and professionalism access contribute to achieving coordination aims using ICTs, during crises periods. In particular, NGOs possess three motivations for working with other relevant agencies; mission, to fulfil a resource need and prior cooperation experience (Ramirez, 2010).

In a related study, Ngamassi, Maitland, and Tapia (2014) revealed that organizations having various ICTs, tend to have a larger network with organizations and display superior performance. Higher levels of network density can, therefore, enhance performance. Social media has recently played a key role in humanitarian crises in disseminating information and armed with this role, an inherent coordination capability and sharing information, resources and plans can be facilitated among relief organizations (Gao, Barbier, \& Goolsby 2011) (refer to Figure 2.7).

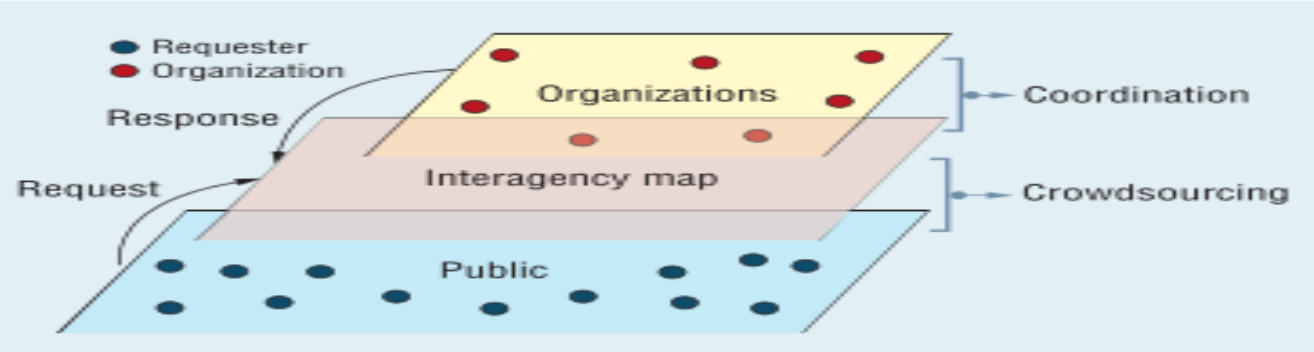

Figure 2: Coordination between the organizations during the relief map through social media (Gao, Barbier, \& Goolsby, 2011).

Additionally, using social media to facilitate coordination among organizations via the development of social capital can assist in preventing duplication of action efforts, poor planning and implementation efforts, and in boosting awareness among the relevant 
organizations about the crisis. The entities can minimize redundancies while assisting in interorganizational information sharing to enhance humanitarian assistance. They also guarantee that member organizations can access the top information and communication technologies and practices while assisting humanitarian crisis (before and after) (Tapia Moore \& Johnson, 2013). The use of social media in emergency response can resolve the usual coordination issues like determining missing persons, facilitating volunteers' communication for coordination and collaboration of assistance in major disaster areas (Yates \& Paquette, 2011).

\section{Response to Humanitarian Crises}

According to the United Nations (UN), humanitarian crisis refers to a serious disruption of the running of society and is a disaster that leads to the damage of extensive human and environmental elements, exceeding the ability of the affected society to cope with using its resource to resolve the crisis. In this case, public volunteers and emergency managers need information and communication system to plan and decide on the actions to adopt (Hiltz, Diaz \& Mark, 2011). In the same line of definition, OCHA (2015) referred to a humanitarian crisis as a singular or series of events that pose threats to the health, safety and wellbeing of the community or a group of people. In this regard, Caitlin (2015) explained that conflict may be internal or external but it frequently impacts a large land area that begs for local, national and international responses for resolution and assistance.

Moreover, humanitarian crisis can be in the form of natural disasters, man-made disasters or great and complex emergencies. The latter arises because of several factors/ events that prevent a group of people from receiving fundamental life needs like food, clean water or safe shelter. This can take the form of armed conflicts, epidemics, famine, natural disasters and other disasters, and when it involves a large influx of people, it could lead to a refugee crisis (United Nations, 2013). A humanitarian crisis can impact the structures of society by disrupting economic development, increasing income and wealth imbalance, ostracizing specific societal groups because of their weak social capital and cohesion and leading to an influx of immigrants.

Furthermore, humanitarian crisis can also result in ineffective capacity and legitimacy of the state to create opportunities for the victims affected by the civil conflict or disaster (Philips, 2009). This makes it important for decision-makers to be kept informed of the optimum elaboration and provision of appropriate resolutions to crises, as acknowledged through knowledge management in social media among organizations and governments throughout the globe (Zlatonova, Oosterom \& Verbree, 2004). Although social media has a positive impact on disaster relief efforts, it falls short of establishing coordination capability for ease of coordination and sharing of information, resources and plans among relief organizations. Therefore, as clarified by Gao, Barbier and Goolsby (2011), social media-based applications offer capabilities to gather information from the crisis area to furnish sufficient evidence to reach informed decisions among the relevant agencies.

\section{METHODOLOGY}

This study adopted a survey as a quantitative research approach, with a correlational method to determine the degree of associations (Creswell, 2013). The study constructs in the context on use of social media by non-profit organizations, with social coordination as an intermediary variable. Positivist epistemological and quantitative methodologies tend to be ideal in this 
research type noted by Wojcieszak, (2012). Accordingly, the empirical approach to collecting and analyzing data is used for this study.

The researchers developed a questionnaire for collecting data. The items of the questionnaire were adapted from previously validated scales from other studies which were employed to gauge the use of social media among non-profit Yemeni organizations during their humanitarian crisis response. Likert scale was used to make a list of possible scaling items for construct and find the subset that measures the various dimensions (Creswell, 2013). The final version of the questionnaire was modified to be relevant to the local context, by translating it into the Arabic Language, and ultimately, distributed. The Arabic translation of the questionnaire was reviewed and approved by two experts. The items comprised of 70 questions separated into five (5) parts.

With regards to the reliability values represented by Cronbach's alpha coefficient, they ranged from 0.855 to 0.907 , with $\mathrm{CR}$ values ranging from 0.838 to 0.902 . The entire values for composite reliability and Cronbach's alpha exceeded the cut-off value (0.60). The present study employed two statistical validity tests; SEM analysis was used to establish convergent validity in the measurement model by determining that the indicators in the scale loaded together on a single construct. Every item loading exceeded 0.50 (0.503 to 0.909). The second validity test was discriminant validity and it verifies that the items developed for measuring different construct are evaluating their corresponding constructs. The Average Variance Extracted (AVE) test for all the constructs are exceeded the cut off value of 0.50 (0.520 to 0.697) as recommended by Fornell and Larcker (1981).

\section{Sample Size}

In Yemen, there are around 8137 non-profit organizations as listed by the Ministry of Social Affairs and Labor. A sample of 381 non-profit organizations is selected randomly from the list with percentage and calculated using Slovin's formula as recommended by Sekaran (2003) and Tabachnick and Fidell (2007).

$$
\begin{aligned}
& \mathrm{n}=\mathrm{N} /(1+\mathrm{Ne} 2) \\
& \mathrm{n}=8137 /(1+8137 *(5 \%) 2) \\
& \mathrm{n}=8137 /\left(1+8137 * 0.05^{*} 0.05\right)=381
\end{aligned}
$$

Where:

$\mathrm{n}$ is the sample size

$\mathrm{N}$ is the population size $=(8137)$

e is the margin of error $=5 \%=0.05$

In the above formula, $\mathrm{n}$ denotes sample size, $\mathrm{N}$ denotes population size (8137) and e denotes the margin of error $(5 \%=0.05)$.

Hence, the sample size was calculated to be 381 organizations but because $100 \%$ response rate is not ensured, the total number of questionnaires distributed among non-profit organizations was 530 questionnaires. From this number, 397 questionnaires were retrieved (75\% rate of response). But because some of the questionnaires had missing values (25), while others had outliers (18), the total number of usable questionnaires remained 354 (73\% rate of 
response). The study's sample size ( $n=354)$ was considered sufficient as it achieved the ratio of 5:1 as suggested by Hair et al. (2011) and Kline et al. (2005).

\section{Limitation}

This study focuses on Hadramout governorate in Yemen because Hadramout has a big number of non-profit organizations that provides volunteering work and relief during the event of humanitarian crises (World Bank, 2013). Moreover, the study focuses only on non-profit organizations as they are the leaders of providing relief during the event of a crisis in Yemen, providing community services, volunteering services and relief activities (International Bank, 2013), and they have the Ministry of Social Affairs permission. Lastly, this study is limited to the online social network of Whatsapp, Facebook and Twitter as they are the top popular social networks online used in Yemen (Adaja \& Ayodel, 2013).

\section{RESULTS AND DISCUSSION}

In this section, the results and the discussion will be shown in three steps; namely descriptive statistics of variables, direct hypothesis results, and indirect hypothesis results.

\section{Descriptive Statistics for Variables}

This study calculated the mean and standard deviation (SD) of the measurement scales with the help of a 5-point Likert scale that ranged from 1 (strongly disagree) to 5 (strongly agree). The study primarily aimed at examining the social media use and social coordination online and their impact on response to humanitarian crises among non-profit Yemeni organizations.

The calculated mean values are tabulated in Table 1, and from the table, the highest mean was obtained by social coordination online (4.143 out of 5) constituting $82 \%$, and in contrast, online knowledge sharing obtained the lowest mean (3.475), constituting $68 \%$, with an overall mean of 3.639 out of 5 (more than 3 ). The descriptive statistics of the study variables are presented in Table 1. Additionally, the standard deviations of the variables ranged from 0.822 to 1.43 , indicating the presence of acceptable variability in the data set. Table 1 shows the descriptive statistics of the variables.

Table 1: Descriptive Statistics for Variables

\begin{tabular}{lllll}
\multicolumn{1}{c}{ Variable } & \multicolumn{1}{c}{ Dimension } & \multicolumn{1}{c}{ Code } & \multicolumn{1}{c}{ Mean } & \multicolumn{1}{c}{ S.D } \\
Social Media Use & Online Access Information & INF & 3.988 & .987 \\
& Online Knowledge Sharing & KNW & 3.475 & 1.143 \\
& Online Interactive & INT & 3.500 & 1.128 \\
& Participation & & & \\
& Social Coordination Online & SCO & 4.134 & .893 \\
& Humanitarian Crises & HUM & 3.711 & .822 \\
Overall & & & 3.639 & .940 \\
\hline
\end{tabular}

\section{Direct Hypothesis Results}

This section presents the empirical study's results, which offer interesting results for discussion, extending prior literature dedicated to the topic. Table 2 contains three direct and 
one indirect hypothesis based on which the aims of this study were developed. The direct and indirect path between the study's variables were all supported.

Empirical evidence from this study shows that there is a significant and positive relationship between the use of social media and social coordination online by NPOs in Hadramout governorate. Thus, hypothesis $\mathrm{H} 1$ is supported. Accordingly, many past studies have obtained similar results and indicated that use of social media by NPOs is a good predictor and plays a very significant role in building of social coordination online (e.g., Wellman \& Hampton, 2001; Blanchard \& Horan, 1998; de Zuniga, Jung \& Valenzuela, 2012; Burke, Kraut \& Marlow, 2011; Valkenburg \& Peter, 2007; Kaigo, 2012).

In the other hand, the results of this study show that coordination online has a significant and positive effect on response to humanitarian crises by NPOs in Hadramout governorate. This result reveals that social coordination online is an important factor that has a strong influence on the speed of response to humanitarian crises in Hadramout. This finding is consistent with the evidence reported in previous research (Schellong, 2007; Jaeger et al., 2007; Williamson, 2011; Shklovski, Palen \& Sutton, 2008; Slagh, 2010).

The relationship between the use of social media and respond to humanitarian crises by NPOs in Hadramout governorate is a significant and positive one. Thus, hypothesis H3 is supported. The results of this study are supported by many previous studies, which asserts the significant effect of social media usage on response to humanitarian crises by NPOs (Panagiotopoulos et al., 2016; Muralidharan et al., 2011; Sutton et al., 2008; Yates \& Paquette, 2010; Aisha, Wok, Manaf \& Ismail, 2015; Ellison, Steinfeld \& Lampe, 2007; Liu \& Jin, 2012).

More specifically, Table 2 shows that social media use is a crucial factor that significantly influences social coordination online and humanitarian crises among Yemeni non-profit organizations with the following results $(\beta=0.333 ; C . R=5.126 ; P=0.000)$ and $(\beta=0.748 ; C . R$ $=6.790 ; \mathrm{P}=0.000$ ) respectively. These support both hypotheses, $\mathrm{H} 1$ and H3. Additionally, social coordination online was found to have a significant and positive effect on the humanitarian crisis $(\beta=0.123 ; C . R=2.659 ; P=0.008)$ and thus supporting $H 2$. Table 2 shows the direct hypotheses results.

Table 2: Direct Hypotheses Testing Result of structural Model

\begin{tabular}{|c|c|c|c|c|c|c|c|c|}
\hline & Exog. & $\Rightarrow$ & Endo. & Estimated & C.R & P-Value & Status & Result \\
\hline H1 & $\begin{array}{l}\text { Use of Social } \\
\text { Media }\end{array}$ & $\Rightarrow$ & $\begin{array}{l}\text { Social Co- } \\
\text { ordination } \\
\text { Online }\end{array}$ & .333 & 5.126 & .000 & Sig. & Supported \\
\hline $\mathrm{H} 2$ & $\begin{array}{l}\text { Social } \\
\text { Coordination } \\
\text { Online }\end{array}$ & $\Rightarrow$ & $\begin{array}{l}\text { Humanitar- } \\
\text { ian } \\
\text { Crisis }\end{array}$ & .123 & 2.659 & .008 & Sig. & Supported \\
\hline H3 & $\begin{array}{l}\text { Use of Social } \\
\text { Media }\end{array}$ & $\Rightarrow$ & $\begin{array}{l}\text { Humanitar- } \\
\text { ian } \\
\text { Crisis }\end{array}$ & .748 & 6.790 & .000 & Sig. & Supported \\
\hline
\end{tabular}




\section{Indirect Hypothesis Results (Social Coordination Online-Mediating Role)}

The obtained findings revealed that social media use influences social coordination online, with standard coefficient of 0.333 (refer to Table 1). The finding also supports the direct influence of social coordination online and response to humanitarian crisis, with standard coefficient 0.123 . Hence, on the basis of the positive direct relationship between social media use and response to humanitarian crisis (0.748).

Therefore, on the basis of the direct positive relationship between social media use and humanitarian crisis response (0.041), the mediating effect of online social coordination on the above relationship was examined. Table 3 shows a significant relationship with social media use indirectly impacting humanitarian crisis response via its effect on social coordination online (0.257). The results evidence the partial mediating effect of social capital online on the social media use-humanitarian crisis response relationship.

Thus, hypothesis $\mathrm{H} 4$ was supported. Because the results regarding the mediating effects represent the major contributions for this study, the questions of why and how mediation of social coordination online takes place could only be answered by theoretical explications rather than past studies. Therefore, important theories including social exchange (Blau, 1964) and the uses and gratifications theory (Katz, Blumber, \& Gurevitch, 1973) provided theoretical bases for the new findings. Table 3 shows the structural parameters of the mediation role of social coordination online for the relationship between social media use and humanitarian crisis.

\section{Table 3: Structural Parameters of the Mediation Role of Social Coordination Online for the Relationship between Social Media Use and Humanitarian Crisis}

\begin{tabular}{|c|c|c|c|c|c|}
\hline & Model & $\begin{array}{l}\text { Direct } \\
\text { effect }\end{array}$ & $\begin{array}{l}\text { Indirect } \\
\text { effect }\end{array}$ & $\begin{array}{l}\text { Significant of } \\
\text { indirect effect }\end{array}$ & Mediation type \\
\hline $\mathrm{H} 1$ & $\begin{array}{l}\text { social media use ---> social } \\
\text { coordination online }\end{array}$ & 0.333 & & $\begin{array}{l}\mathrm{P}=0.000 \\
\text { Significant }\end{array}$ & $\begin{array}{l}\text { Partial } \\
\text { Mediation }\end{array}$ \\
\hline $\mathrm{H} 2$ & $\begin{array}{l}\text { social coordination online -----> } \\
\text { humanitarian crisis }\end{array}$ & 0.123 & & $\begin{array}{l}\mathrm{P}=0.000 \\
\text { Significant }\end{array}$ & \\
\hline $\begin{array}{l}\mathrm{H} 3 \\
\text { and } \\
\mathrm{H} 4\end{array}$ & $\begin{array}{l}\text { social media use ---> } \\
\text { humanitarian crisis } \\
\text { Via social coordination online }\end{array}$ & 0.567 & 0.041 & $\begin{array}{l}\mathrm{P}=0.007 \\
\text { Significant }\end{array}$ & \\
\hline
\end{tabular}

Generally, the results of this study show that coordination online has a significant and positive effect on response to humanitarian crises by NPOs in Hadramout governorate. This result reveals that social coordination online is an important factor that has a strong influence on speed of response to humanitarian crises in Yemen. This finding is consistent with the evidence reported in previous research (Schellong, 2007; Jaeger et al., 2007; Williamson, 2011; Shklovski, Palen \& Sutton, 2008; Slagh, 2010).

The results suggest that NPOs focus on social coordination among the victims through social media to facilitate humanitarian crises response in a timely manner. This reveals that NPOs in Yemen could encourage social media use during humanitarian crises as this could lead to better coordinate during humanitarian crises among victims and organizations (Rogstadius \& Vukovic, 2011). 


\section{CONCLUSION}

This study set out to determine the relationship between social media use, social coordination and response to humanitarian crisis among Yemeni non-profit organizations. The study also examined the mediating role of social coordination online on the relationship between social media use and response to humanitarian crisis. The results showed a significant and positive relationship between social media use and response to humanitarian crisis, and between social coordination online and response to humanitarian crisis. The results also showed social coordination online to mediate the social media use-response to humanitarian crisis relationship in Yemeni non-profit organizations. The present study is an extension of cognitive engagement, with the U\&G theory that has been previously utilized by scholars in traditional mass media and internet marketing. The study results have several implications. Through practice, preparation and familiarity, social media can be useful in responding to humanitarian crises. Social media use and social coordination online are effective tools in crises situations and through their optimal use, responders can promote humanitarian imperative and lessen the victims' suffering. The study can be used as a guide by practitioners, social policy makers, government and non-governmental institutions and non-profit organizations as well as the media to promote citizen participation in social life decisions during crises, in Middle Eastern countries, particularly Yemen.

\section{RECOMMENDATIONS AND FUTURE STUDIES}

Based on the results, several inferences can be made. It can be concluded that there are different antecedents of social coordination online during humanitarian crises. As shown by the current study, access to information, knowledge sharing and interactive participation were found to be important determinants of the social coordination online. But in addition to these bonds, this study suggests other factors that may have an important influence on the social coordination online such as social satisfaction and social motivation and crowdsourcing. Future studies could add to these existing findings by examining the relationships between motivations to use social media and new technologies for information sharing, and how these needs were gratified with specific use of social media for information sharing, in the context of specific types from natural disasters in Yemen.

Finally, majority managers of NPOs in Yemen governorate are not aware of the many benefits of social media use during humanitarian crises adoption and the promotion of this awareness through information and training programs is thus necessary. Moreover, the Yemen government should improve the infrastructure to emergencies centers and information collection through benefit from new networks communication use and social media information. At the same context, NPOs need to adopt new media system in their response to humanitarian crises because they need to speed in the collect of information in order to early response.

\section{ACKNOWLEDGEMENT}

We would like to extend our gratitude to those who participated in the survey questionnaire. This project is supported by A Lawn Foundation for Development and Benevolent Fund for outstanding Yemeni students. 


\section{REFERENCE}

Abbasi, M. A., Kumar, S., Andrade Filho, J. A., \& Liu, H. (2012, April). Lessons learned in using social media for disaster relief-ASU crisis response game.. In International Conference on Social Computing, Behavioral-Cultural Modeling, and Prediction (pp. 282-289). Berlin, Heidelberg: Springer.

Adaja, T. A. \& Ayodele, F. A. (2013). Nigerian youths and social media: Harnessing the potentials for academic excellence. Singaporean Journal of Business, Economics and Management Studies, 51 (1108), 1-11.

Aisha, T. S., Wok, S., Manaf, A. M. A., \& Ismail, R. (2015, September). Exploring the use of social media during the 2014 flood in Malaysia. Procedia - Social and Behavioral Sciences, 211, 931-937. Retrieved from http://linkinghub.elsevier.com/retrieve/pii/ S1877042815054634.

Alexander, D. E. (2014). Social media in disaster risk reduction and crisis management. Science and Engineering Ethics, 20 (3), 717-733.

Blanchard, A. L., \& Horan, T. (1998). Virtual communities and social capital. Social Science Computer Review, 16, 6-21. Retrieved from http://ssc.sagepub.com/cgi/ doi/10.1177/089443939801600306.

Caitlin. (2015). Top 10 needs facing refugees and those displaced in emergencies. Women's Refugee Commission. Retrieved 9 February 2015 from womensrefugeecommission.org.

Blau, P. M. (1964). The dynamics of bureaucracy: Study of interpersonal relations in two government agencies (Rev. ed.). University of Chicago Press: Chicago.

Blumler, J. G., \&; Katz, E. (1974). The uses of mass communications: Current perspectives on gratifications research (Vol. 1974). London: Sage Publications, Inc.

Burke, M., Kraut, R., \& Marlow, C. (2011). Social capital on fakebook. Proceedings of the 2011 Annual Conference on Human Factors in Computing Systems - CHI '11, 571. Retrieved from http://dl.acm.org/citation.cfm?id=1978942.1979023

Castillo, C., Mendoza, M., \& Poblete, B. (2011). Information credibility on twitter. Proceedings of the 20th International Conference on World Wide Web - WWW '11, 675. Retrieved from http://portal.acm.org/citation.cfm?doid=1963405.1963500.

Ceron, A., Curini, L., Iacus, S. M., \& Porro, G. (2014). Every tweet counts? How sentiment analysis of social media can improve our knowledge of citizens' political preferences with an application to Italy and France. New Media \& Society, 16, 340-358. Doi: $10.1177 / 1461444813480466$.

Chang, K. (2010). Community cohesion after a natural disaster: insights from a Carlisle flood. Disasters, 34 (2), 289-302.

Chou, K. C., \& Cai, Y. D. (2005). Using GO-PseAA predictor to identify membrane proteins and their types. Biochemical and Biophysical Research Communications, 327 (3), 845-847.

Creswell, J. W. (2013). Research design, qualitative, quantitative, and mixed methodes approaches. London: SAGE.

Dantas, A., \& Seville, E. (2006). Organisational issues in implementing an information sharing framework: lessons from the Matata flooding events in New Zealand. Journal of Contingencies and Crisis Management, 14(1), 38-52.

de Zúñiga, G. H., Jung, N., \& Valenzuela, S. (2012). Social media use for news and individuals' social capital, civic engagement and political participation. Journal of Computer-Mediated Communication, 17(3), 319-336. 
Dynes, R. R., \& Disaster. (2002). The importance of social capital in disasters response. Newark: University of Delaware.

Goolsby, R. (2010). Social media as crisis platform. ACM Transactions on Intelligent Systems and Technology, 1 (1), 1-11.

Ellison, N. B., Vitak, J., Steinfield, C., Gray, R., \& Lampe, C. (2011). Negotiating privacy concerns and social capital needs in a social media environment. In S. Trepte \& L. Reinecke Privacy online (pp. 19-32). London: Springer.

Gao, H., Barbier, G., \&; Goolsby, R. (2011). Harnessing the crowdsourcing power of social media for disaster relief. IEEE Intelligent Systems, 26 (3), 10-14.

Fornell, C., \& Larcker, D. F. (1981). Structural equation models with unobservable variables and measurement error: Algebra and statistics. Journal of marketing research, 382-388

Hair, J. F., Ringle, C. M., \& Sarstedt, M. (2011). PLS-SEM: Indeed, a silver bullet. Journal of Marketing Theory and Practice, 19 (2), 139-152.

Hiltz, S. R., Diaz, P., \& Mark, G. (2011). Introduction: social media and collaborative systems for crisis management. ACM Transactions on Computer-Human Interaction, 18 (4), 1-6. Retrieved from http://dl.acm.org/citation.cfm?doid=2063231.2063232.

Jaeger, P. T., Fleischmann, K. R., Preece, J., Shneiderman, B., Wu, P. F., \& Qu, Y. (2007). Community response grids: Using information technology to help communities respond to bioterror emergencies. Biosecurity and Bioterrorism: Biodefense Strategy, Practice, and Science, 5 (4), 335-45.

Kapoor, K. K., Tamilmani, K., Rana, N. P., Patil, P., Dwivedi, Y. K., \& Nerur, S. (2018). Advances in social media research: past, present and future. Information Systems Frontiers, 20 (3), 531-558.

Katz, E., Blumler, J. G., \& Gurevitch, M. (1973). Uses and gratifications research. The Public Opinion Quarterly, 37(4), 509-523.

Kaigo, M. (2012). Social media usage during disasters and social capital: Twitter and the Great East Japan earthquake. Keio Communication Review, 34 (1), 19-35.

Kaye, B.K. \& Johnson, T.J. (2002). Online and in the know: Uses and gratifications of the Web for political information. Journal of Broadcastings \& Electronic Media, 46 (1), 54-71.

Kendra, J. M., \& Wachtendorf, T. (2006). Improvisation, Creativity and the Art of Emergency Management' in Disaster Research Center Preliminary Paper\# 357. University of Delaware

Kreps, GA (1989). Social structure and disaster. Newark, London, and Toronto: University of Delaware and Associated University Presses.

Kline, R. J., McGehee, M. D., Kadnikova, E. N., Liu, J., Fréchet, J. M., \& Toney, M. F. (2005). Dependence of regioregular poly (3-hexylthiophene) film morphology and field-effect mobility on molecular weight. Macromolecules, 38 (8), 3312-3319.

Kumar, S., Barbier, G., Abbasi, M. A., \&; Liu, H. (2011, July). TweetTracker: An analysis tool for humanitarian and disaster relief. In N. Nicolov \& J. G. Shanahan Proceedings of the fifth international conference on weblogs and social media (pp 661-662). California: The AAAI Press.

Leidner, D. E., Pan, G., \& Pan, S. L. (2009). The role of IT in crisis response: Lessons from the SARS and Asian Tsunami disasters. The Journal of Strategic Information Systems, 18(2), 80-99.

Liu, B. F., Fraustino, J. D., \& Jin, Y. (2015). Social media use during disasters: how information form and source influence intended behavioral responses. Communication Research. Retrieved from http://crx.sagepub.com/cgi/doi/10.1177/0093650214565917. 
Liu, D., Ainsworth, S. E., \& Baumeister, R. F. (2016). A meta-analysis of social networking online and social capital. Review of General Psychology, 20 (4), 369-391.

Liu, B. \& Jin, Y. (2012). Social media use during disasters: a review of the knowledge base and gaps. Final Report to Human Factors/Behavioral Sciences Division. Science and Technology Directorate. US Department of Homeland Security. College Park.

Maxwell, E. M. (2012). Motivations to tweet: A uses and gratifications perspective of Twitter use during a natural disaster. Doctoral dissertation. The University of Alabama.

Muralidharan, S., Rasmussen, L., Patterson, D., \& Shin, J. H. (2011). Hope for Haiti: An analysis of Facebook and Twitter usage during the earthquake relief efforts. Public Relations Review, 37 (2), 175-177. Doi: 10.1016/j.pubrev.2011.01.010.

Moore, S., Eng, E., \& Daniel, M. (2003). International NGOs and the role of network centrality in humanitarian aid operations: a case study of coordination during the 2000 Mozambique floods. Disasters, 27 (4), 305-318.

Ngamassi, L., Maitland, C., \& Tapia, A. H. (2014). Humanitarian interorganizational information exchange network: how do clique structures impact network effectiveness? VOLUNTAS: International Journal of Voluntary and Nonprofit Organizations, 25 (6), 14831508.

Noonan, C., Sommer, S. A., Hadley, C. N., \& Pittinsky, T. L. (2016). Measuring the efficacy of leaders to assess information and make decisions in a crisis: The C-LEAD Scale. The Leadership Quarterly, 22, (4), 633-648.

OCHA. (2015). Humanitarian Response Plan 2014 in Yemen. Sana. https://www. humanitarianresponse.info/system/files/documents/files/2015\%20Revised\%20YHRP Final1_0.pdf

Panagiotopoulos, P., Barnett, J., Bigdeli, A. Z., \& Sams, S. (2016). Social media in emergency management: Twitter as a tool for communicating risks to the public. Technological Forecasting and Social Change, 111, 86-96.

Panahi, S., Watson, J., \& Partridge, H. (2012). Social media and tacit knowledge sharing: developing a conceptual model. World Academy of Science, Engineering and Technology, 64, 1095-1102.

Phillips, D. (2009). Online public relations: A practical guide to developing an online strategy in the world of social media. New York: Kogan Page Publishers.

Postigo, H. (2009). America online volunteers: Lessons from an early co-production community. International Journal of Cultural Studies, 12, 451-469.

Purohit, H., Hampton, A., Bhatt, S., Shalin, V. L., Sheth, A. P., \& Flach, J. M. (2014). Identifying seekers and suppliers in social media communities to support crisis coordination. Computer Supported Cooperative Work (CSCW), 23 (4-6), 513-545.

Ramirez, M., Balcik, B., Beamon, B. M., Krejci, C. C., Muramatsu, K. M., (2010). Coordination in humanitarian relief chains: Practices, challenges and opportunities. International Journal of Production Economics, 126 (1), 22-34.

Reuter, C. \& Kaufhold, M. A. (2018). Fifteen years of social media in emergencies: a retrospective review and future directions for crisis informatics. Journal of Contingencies and Crisis Management, 26 (1), 41-57. 
Rogstadius, J., Kostakos, V., Laredo, J., \& Vukovic, M. (2011). Towards real-time emergency response using crowd supported analysis of social media. In D. Tan (Ed.) Proceedings of CHI workshop on crowdsourcing and human computation, systems, studies and platforms. Nwe York: Association for Computing Machinery.

Ruggiero, T. E. (2000). Uses and gratifications theory in the $21^{\text {st }}$ century. Mass communication $\mathcal{E}$ Society, 3 (1), 3-37.

Saab, D. J., Maitland, C., \& Tapia, A. H. (2008, May). Building global bridges: Coordination bodies for improved information sharing among humanitarian relief agencies. In F. Fiedrich B. van der Welle (Eds). Proceedings of the 5th International ISCRAM Conference, (pp. 471-483). Baden-Baden: Karlsruher Institut fur Technologie..

Scalese, A. J. (2012). A weapon of technology: how the internet has changed the conflict landscape in the age of instant information. PhD Dissetation. George Mason University.

Schellong, A. (2007). Increasing social capital for disaster response through social networking services (SNS) in Japanese local governments. NCDG Working Paper No. 07-005. National Center for Digital Governmant.

Sekaran, S., Foster, R. G., Lucas, R. J., \&amp; Hankins, M. W. (2003). Calcium imaging reveals a network of intrinsically light-sensitive inner-retinal neurons. Current Biology, 13 (15), 1290-1298.

Shklovski, I., Palen, L., \& Sutton, J. (2008, November). Finding community through information and communication technology in disaster response. In B. Begole \& D. W McDonald (Eds.).Proceedings of the 2008 ACM Conference on Computer Supported Cooperative Work.(pp. 127-136). New York: Association of Computing Mechinery. Retrieved from http://dl.acm.org/citation.cfm?id=1460584.

Slagh, C. (2010). Managing chaos, 140 characters at a time: How the usage of social media in the 2010 Haiti crisis enhanced disaster relief. Doctoral Dissertation. Georgetown University.

Stephenson, R., \& Anderson, P.S. (1997). Disasters and the information technology revolution. Disasters, 21 (4), 305-334.

Stewart, G. T., Kolluru, R., \& Smith, M. (2009). Leveraging public-private partnerships to improve community resilience in times of disaster. International Journal of Physical Distribution \& Logistics Management, 39 (5), 343-364.

Stieglitz, S., Bunker, D., Mirbabaie, M., \& Ehnis, C. (2018). Sense-making in social media during extreme events. Journal of Contingencies and Crisis Management, 26 (1), 4-15.

Sutton, J., Palen, L., \& Shklovski, I. (2008, May). Backchannels on the front lines: Emergent uses of social media in the 2007 southern California wildfires. In F. Fiedrich B. van der Welle (Eds), Proceedings of the 5th International ISCRAM Conference, (pp.1178-1204). BadenBaden: Karlsruher Institut fur Technologie.

Tabachnick, B. G., \& Fidell, L. S. (2007). Using multivariate statistics, (3rd Ed.). New York: Pearson.

Tapia, A. H., Moore, K. A., \& Johnson, N. J. (2013, May). Beyond the trustworthy tweet: A deeper understanding of microblogged data use by disaster response and humanitarian relief organizations. In F. Fiedrich B. van der Welle (Eds). Proceedings of the 5 th International ISCRAM Conference, (pp. 770-779). Baden-Baden: Karlsruher Institut fur Technologie.

Tchouakeu, N. L-M, Maldonado, E. Kang Zhao, Robinson, H., Maitland, C., \& Tapia, A (2011) Exploring barriers to coordination between humanitarian NGOs: A comparative case 
study of two NGO's information technology coordination bodies. In John Wang (ed.) Information systems and modern society: Social change and global development (pp. 87-112) Pennsylvania: IGI Global.

Tucker, C. (2011). Social media, texting play new role in response to disasters: preparedness, communication targeted. The Nation's Health, 41(4), 1-18.

United Nation, (2015). Protecting Women in Emergency Situation.. UNFPA.org. Retrieved 9 February. www.unfpa.org/resources/protecting-women-emergency-situations

Valkenburg, P. M., \& Peter, J. (2007). Online communication and adolescent well-being: Testing the stimulation versus the displacement hypothesis. Journal of Computer-Mediated Communication, 12 (4), 1169-1182.

Wachtendorf, T. (2004). Improvising 9/11: Organizational improvisation following the world Trade Center Disaster by. Delaware. Retrieved from https://scholar.google.com/scholar ?q=Wachtendorf, $+2004 \& b \operatorname{tnG}=\& h l=e n \& a s \_s d t=0,5$.

Wellman, B., Haase, a. Q., Witte, J., \&; Hampton, K. (2001). Does the internet increase, decrease, or supplement social capital? Social networks, participation, and community commitment. American Behavioral Scientist, 45 (3), 436-455.

Westerman, D., Spence, P. R., \& Van Der Heide, B. (2012). A social network as information: The effect of system generated reports of connectedness on credibility on Twitter. Computers in Human Behavior, 28 (1), 199-206.

Wilson, J. (2012). Responding to natural disasters with social media: a case study of the 2011 earthquake and tsunami in Japan. MA Thesis. Scholl of International Studies. Simon Fraser Unversity.

Williamson, A. (2011, April 7-9). Driving CIVIC participation through social media. European workshop: Perspectives of Web 2.0 for Citizenship Education in Europe. Brno, Czech Republic: Netwoking European Citizen Edication.

Williams, D.L., Crittenden, V.L., Keo, T. \& McCarty, P. (2012). The use of social media: An exploratory study of uses among digital natives. Journal of Public Affairs, 12 (2), 127-136.

Wojcieszak, M. (2012). Transnational connections symposium: challenges and opportunities for political communication research - introduction. International Journal of Communication 6, 255-265.

World Bank. (2013). Yemen Civil Society Organizations in transition. Sana. Retrieved fromhttps://openknowledge.worldbank.org/bitstream/handle

Wright, D. K., \& Hinson, M. D. (2009, March). An analysis of the increasing impact of social and other new media on public relations practice. In $12^{\text {th }}$ annual International Public Relations Research Conference. Miami, Florida.

Yates, D., \& Paquette, S. (2011). Emergency knowledge management and social media technologies: A case study of the 2010 Haitian earthquake. International Journal of Information Management, 31 (1), 6-13. Retrieved from http://dx.doi.org/10.1016/j. ijinfomgt.2010.10.001.

Yemen, S. H. (2015). How the impact of a hurricane, "Tshabalala," and Meg "positively on the lives of the people of Yemen Socotra? e (Vol. 1). Sana. Retrieved from http://www. sahafah.net/show2201096.html.

Zakour, M. (2008). Social capital and increased organizational capacity for evacuation in natural disasters. Social Development Issues, 30 (1), 13-28. 
Zlatanova, S., Van Oosterom, P., \& Verbree, E. (2004, July). 3D technology for improving disaster management: Geo-DBMS and positioning. In M.O. Altan (Ed.). Proceedings of the $X X$ th ISPRS congress. Istanbul: International Society for Photogrammetry and Remote Sensing. 